\title{
УДК 882
}

DOI $10.17223 / 18137083 / 66 / 5$

\section{И. А. Айзикова}

Томский государственный университет

\section{Тема Палестины в творческом диалоге В. А. Жуковского и А. Н. Муравьева ${ }^{*}$ Статья вторая}

\begin{abstract}
Обозреваются темы и идеи А. Н. Муравьева, отразившиеся в «Путешествии ко Святым местам» и ставшие в 1840 -е гг. предметом внимания В. А. Жуковского в его религиознофилософской, публицистической прозе, эпистолярии и поэме «Странствующий жид». Важнейшие из них связаны с осмыслением святынь Иерусалима как метафизического феномена, содержащего ответ на все больные вопросы истории и современности, со стремлением к освобождению Святого Гроба из-под власти турецкого султана и с особым вниманием к России и фигуре русского царя, способных выполнить возложенную на них свыше миссию. Переклички Муравьева и Жуковского объясняются сходством духовных исканий, идейной близостью, во многом диктуемой временем.

Ключевые слова: В. А. Жуковский, А. Н. Муравьев, тема Палестины, творческий диалог.
\end{abstract}

Нам уже приходилось писать о так называемом Иерусалимском проекте В. А. Жуковского - о его предложении освободить храм Гроба Господня и Иерусалим из-под власти турецкого султана, высказанном в письме к великому князю Константину Николаевичу, датируемом концом 1849 г.: «Иерусалим должен принадлежать христианскому миру, и рабство гроба Христова должно быть наконец уничтожено» [Жуковский, 1878, с. 378]. Рассматривая его в связи с комплексом поздних идей Жуковского о возможности возвращения идеала в земную жизнь, его соединения с действительностью, как «поэтическое дело», которое сведет «божественное на землю», а реальное возведет «от земного к божественному»

\footnotetext{
* Исследование выполнено при финансовой поддержке РГНФ. Совместный конкурс научных проектов РГНФ - Императорское православное Палестинское общество (проект № 15-64-01001).

Айзикова Ирина Александровна - доктор филологических наук, профессор, заведующая кафедрой общего литературоведения, издательского дела и редактирования Томского государственного университета (просп. Ленина, 36, Томск, 634004, Россия; wand2004@mail.ru)
}

ISSN 1813-7083. Сибирский филологический журнал. 2019. № 1

(C) И. А. Айзикова, 2019 
и им дополнит «все земное, столь мало удовлетворительное и столь неверное» [Жуковский, 1878, с. 377], мы квалифицировали проект как речевой акт, воплощающий те же внутренние интенции и посылы авторского сознания, что и поэма «Странствующий жид», перевод «Одиссеи», религиозно-философская и публицистическая проза поэта, в которых попытка решать политические вопросы неизменно уводила писателя в область религии, этики и эстетики. Отмечалось также, что идея синтеза, взаимосвязи и взаимодействия этих сфер жизни человечества в 1830-1840-е гг. привлекала многих современников Жуковского, органично вписываясь в принципиальный интерес русского общества к идее «единой всеобщей основы» ${ }^{1}$, за которой, как известно, было большое будущее и в русской литературе, и в русской религиозной философии (см.: [Айзикова, 2017]).

Вопрос о природе и сути Иерусалимского проекта поэта-романтика активно обсуждается в современной науке. В предлагаемой статье обратимся к значительно менее изученным предложениям А. Н. Муравьева, высказанным в «Путешествии ко Святым местам», и контекстам, в которых они звучат, весьма характерно перекликающимся с проектом Жуковского, эквивалентным многим статьям писателя 1840-х гг. Эти переклички, конечно, не являют собой диалог в бахтинском смысле, поскольку они не были вызваны интенсивным творческим общением, литературными или житейскими обстоятельствами ${ }^{2}$ и объясняются сходством духовных исканий, идейной близостью, во многом диктуемым временем.

Уже упоминавшаяся нами статья А. С. Пушкина «"Путешествие к Св. местам" А. Н. Муравьева» открывается следующим положением: «В 1829 году внимание Европы было обращено на Адрианополь, где решалась судьба Греции, целые 8 лет занимавшей помышления всего просвещенного мира. <..> Во время переговоров, среди торжествующего нашего стана, в виду смятенного Константинополя, один молодой поэт думал о ключах св. храма, о Иерусалиме, ныне забытом христианскою Европою» [Пушкин, 1964, с. 263]. «Путешествие ко Святым местам» открывается главами «Адрианополь» и «Мир», посвященными описанию атмосферы подготовки Адрианопольского мирного договора и ожидания его ратифицирования, возвращения русских полков в Россию. Повествователь (автор и герой-путешественник, по сути дела выступающие в одном лице) в это время, чувствуя свою отчужденность от происходящего, ощущая «вечную черту», разделяющую его с товарищами, собирающимися на родину, думает «о той отдаленной цели, мимо коей лежал» для него «единственный путь к возвращению, через столько морей и пустынь» - о посещении Святой Земли [Муравьев, 2006, с. 68].

Путь повествователя к Иерусалиму лежит через территорию древней Византии, примечательно названную в «Путешествии...» «священной стезей развалин». В отличие от Жуковского, который никогда не был в Палестине и собирал «локальные краски» [Гоголь, 2009, с. 297] о ней для своих оригинальных и переводных произведений, изучая множество изданий по библейской истории и географии, описания Муравьева подробны, отобранные детали подчеркивают атмосферу, которую лично ощутил и пережил повествователь: «...самая патриархия, сооруженная во имя Божией Матери... была последним приютом патриархов, со дня завоевания постепенно изгоняемых из великолепных храмов. <..> Церковь греческая, приходившая постепенно в упадок со времени завоевания оттоманского... претерпела тяжкое гонение» и лишилась «лучших своих светильников, мученически пострадавших. <..> Только в стенах монастырских можно было находить некий приют от гонения». С радостью находя сходства церкви российской и гре-

\footnotetext{
${ }^{1}$ Понятие, предложенное В. С. Соловьевым в его «Философии искусства и литературной критики», являющее собой, как известно, развитие идеи «единства во множестве».

${ }^{2}$ О степени знакомства и близости отношений В. А. Жуковского и А. Н. Муравьева см. в первой части данной статьи [Айзикова, 2018]
} 
ческой, он все же неприятно поражен звучанием греческого церковного хора, не постигающего «гармонии нашей», обращает внимание на «недостаток благочиния в храме... вкоренившееся под игом турков... <..>. Самые священнослужители привыкли более видеть в церкви дом свой, нежели храм» [Муравьев, 2006, с. 84, $86-87]^{3}$.

Душа путешественника-повествователя «пламенно» желает Земли Обетованной, и грудь его «облегчилась» только по прибытии в Газу. Но первые впечатления: все зелено, живописно, дорога пролегает через обработанные поля, Газа богатый город, использующий свое удачное географическое расположение, - скоро осложняются мотивами разрушения, политической и духовной нестабильности, антихристианского гнета, засилья мусульман, вплоть до террора, которые между тем последовательно уравновешиваются идеей способности православных христиан, обитающих на Святой Земле, защищать свою веру от чужеродных наслоений, быть гибкими для сохранения внутренней верности заветам Христа.

В Газе повествователь, например, был сражен необходимостью целовать край одежды и руку «мусселима», что почиталось «священным долгом» для всех. Но не меньше этого он был поражен встречей с арабами, исповедующими христианство, пожалуй самыми гонимыми в Газе, - их интересовал лишь один вопрос, освобождены ли Иерусалим и Гроб Господень в результате Адрианопольского мира. По дороге в Раму он замечает, что от многолюдных древних поселений «остались слабые развалины», Рама, стоящая «на перепутьи к Иерусалиму от Яффы», была воспринята повествователем как «пристанище трех религий» [Там же, c. 152] $]^{4}$ и место постоянных религиозных разногласий, провокаций и конфликтов. Однако в первый же вечер по его приезду в Раму собрались «все христианские старшины города» и речь шла опять «о войне с турками и о мире, равно и об освобождении Святого Гроба, единственной и вечной цели желаний христианского Востока». Здесь же игумен Захария, содержавший гостиницу на греческом подворье, показал русскому путешественнику «рукопись, заключающую в себе пророчества монаха Агафангела, жившего в XIII веке, о славе России... Игумен прочел мне в рукописи о величии Петра, Екатерины, о нашествии галлов и нового царя их, ведущего их на гибель, и о славе Александра» [Там же, с. 152].

Уже в первых главах «Путешествия...» Муравьев вводит многие темы и идеи, чуть позже ставшие предметом внимания Жуковского в его религиознофилософской, публицистической прозе, эпистолярии и «лебединой песне» поэта поэме «Странствующий жид». Важнейшие из них связаны с осмыслением Гроба

\footnotetext{
${ }^{3} \mathrm{Cp}$., напр., описание Иерусалима, покинутого Сыном Божьим, из поэмы «Странствующий жид». Оно содержит множество деталей-символов, мифологем, складывающихся в богатую смысловую систему: «утих Ерусалим. Во мгле громадой безобразной зданья / чернели. Жители все затворились / В своих домах, и все тяжелым сном / Заснуло» [Жуковский, 2009, с. 267]. Одновременно вводятся образы звезд как открывшихся над Иерусалимом «окон», небесного света, проливающегося на землю, и расчистившегося неба. Установившаяся над городом тишина «невыразима и неизглаголанна», «и слуху сердца слышалося там, как от звезды к звезде перелетали / Их стражи - ангелы, с невыразимой / Гармонией блаженной чудной вести» [Там же, с. 268], над Элеонской горой встает заря («звезда денницы подымалась»). Мотивы тяжелого сна, мглы, грохота, черноты, всеобщего разрушения и беспорядка усиливают поэтический эффект символических подробностей. Подробнее см. об этом: [Айзикова, 2015; 2016], а также в первой части данной статьи [Айзикова, 2018].

${ }^{4}$ Далее следует чрезвычайно красноречивое описание селения Абугоша, находящегося в трех часах езды от Иерусалима и как в зеркале отражающего положение дел в Святой Земле: «Латины признают место сие отчизной пророка Иеремии; греки предполагают здесь древний Эммаус... Шейх Абугош... избрал себе место сие... Охраняя дорогу из Рамы в Иерусалим от набега бедуинов... он брал произвольную подать со всех христиан» [Муравьев, 2006, с. 154].
} 
Господня и других святынь Иерусалима, их трагической истории как некого метафизического феномена, содержащего ответ на все больные вопросы прошлого и современности, со стремлением к освобождению Святого Гроба и с особым вниманием к России и фигуре русского царя, способных выполнить возложенную на них свыше миссию.

Так, красной нитью, через все «Путешествие...» проходит мысль о том, как волнующи и непередаваемы словом переживания, испытываемые героем-повествователем при встрече с Иерусалимом и другими святыми местами Палестины, они воспринимаются им как озарение, чудесное внутреннее преображение: «Кто выразит все чувства, волнующие грудь, при внезапном появлении Святого Града? И можно ли изъяснить речами то тайное борение радости и страха, которыми попеременно движется сердце в сие торжественное мгновение, когда все дивные имена Сиона, Голгофы и Элеона... внезапно олицетворяются перед очарованными глазами» [Муравьев, 2006, с. 156].

Утешающе, отрадно действуя на душу, звучат для повествователя стихиры Великого четверга, в его присутствии исполненные хором священников в синодике и сопровождающие совершающийся над ним обряд умывания ног и рук, который напомнил ему «первые обряды христианства». «Тихое, сладкое благоговение проникает душу» повествователя в церкви Успения Богородицы: «Тусклая лампада, теплясь в углублении, слабо освещает две фигуры: ангела и повергшегося на землю Спасителя. Здесь дивное существо Его ближе, понятнее сердцу» [Там же, c. 164]. Каждый шаг во глубину храма Гроба Господня в представлении повествователя «есть как бы шаг в вечность, ибо на каждом встречается какое-либо великое воспоминание, тесно связанное с бытием нашим, но не с мгновенным, житейским бытием. Нет, падение всего человечества, его искупление и грядущая жизнь - вот три необъятные бездны, в пространстве коих носится смятенная мысль, падая и восставая под бременем высоких впечатлений, сообразно с дивной местностью Храма». Камень миропомазания в нем воспринимается повествующим героем «как оселок веры», он лежит в преддверии, «на падение и на восстание многим». «Покаянные мысли о грехе, мольбы о спасении, вздохи и порывы к испустившему последний вздох свой на кресте, весь ужас дрогнувшей Голгофы и померкшего солнца, и вся радость разбойника, первого наследника рая, - такова буря духовная, потрясающая на Голгофе бренное естество человека!» [Там же, c. 195,209$]^{5}$

Последовательно через все описание пребывания повествователя в Святой Земле используется мотив душевной и духовной радости, просветления. Он радуется теплому приему, который, как правило, оказывался ему как представителю России большинством тех, с кем ему приходится общаться на Святой Земле. Он

\footnotetext{
${ }^{5}$ Ср. с описанием поведения Агасвера, взошедшего на Голгофу, переданного с помощью таких деталей-символов: он плачет, «простирается в прах» на месте, где был водружен крест, его сердце «трепещет» от терзаний и благодарности. Здесь, на фоне «страшного разрушения земных величий», происходит его очищение от греха и воскресение к новой жизни с Богом в душе, «невыразимое словами человеческими». Спустившись с Голгофы, Агасвер направляется через Кедрон, «по скату Элеонской горы» в Гефсиманский сад, где «вспоминает» слова Христа, которые он не мог слышать ранее, - это слова, произнесенные Им «в смертельной тоске» «на поученье и на подпору всем земным страдальцам». Постигший «благо казни» на Голгофе, куда его Господь привел во второй раз, он ощущает, что озлобленность его души переродилась в смирение благодаря божьей благодати, каковым было и посланное ему Богом наказание. Из разрушенного Иерусалима герой отправляется «перерожденный, новый», по собственной воле «взяв на плеча весь груз» своей судьбы и «сокрушенно» своей вины «всю глубины измерив». Свой путь, длиной более чем в тысячелетие, герой отсчитывает от «той границы, на которой мир древний кончился, где на его могиле колыбель свою поставил новорожденный мир» [Жуковский, 2009, с. 307].
} 
умилен своими соотечественниками, сумевшими не потерять себя и своей веры, оказавшись в тяжелейшей ситуации антихристианского гнета. Со светлой грустью он преклоняется перед памятью многих иноков, священников, отдавших жизнь вере в Христа или принявших мученическую смерть за нее. Примеры можно продолжать, однако подчеркнем главное - необычайную близость взглядов Муравьева к толкованию святынь Иерусалима Жуковским в его поздних религиозно-философских статьях и поэме «Странствующий жид» (подробно об интерпретации святынь Иерусалима у Жуковского см.: [Айзикова, 2004; 2015; 2016]).

Не менее близки писатели в своих идеях спасения Гроба Господня и той роли, которую могут и должны сыграть в этом Россия и русский монарх, хотя акценты каждым из них расставлены свои.

В частности, не противопоставляя в деле спасения христианского мира Россию Западу, погрязшему в духовном и религиозном кризисе, как это делал Жуковский в своей публицистике, Муравьев отыскивает практически те же черты упадка на Востоке, в современных ему Палестине и Иерусалиме: отрицание вечных устоев, безбожие, эгоизм, погоня за материальными благами, способная обернуться необратимыми гибельными последствиями (и здесь он очень близок авторской позиции в поэме Жуковского «Странствующий жид»). Так, первые слова, услышанные повествователем на родном языке в Иерусалиме, исходили из уст русских монахов и послушников, встречавших его у ворот «патриаршей обители»: это были жалобы «на гонения и совершенную нищету, которые они истинно претерпевают» [Муравьев, 2006, с. 157]. Встретивший его наместник Мисаил, духовник всех русских православных в Иерусалиме, описан физически немощным и не участвующим в управлении церкви, положение второго наместника Даниила, по словам путешествующего повествователя, тоже «весьма тягостно по беспрестанным притеснениям властей арабских и совершенному упадку благосостояния Иерусалимской церкви», казна которой пуста [Там же] ${ }^{6}$

«Горькое впечатление оставила в сердце» повествователя первая обедня в Гефсимании. Слух и взоры, привыкшие на православной родине к глубочайшему благоговению в храмах, странно были поражены «нестройностью служения и бесчинием толпы. <..> Оскорбительнее всего было видеть стража арабского, всегда идущего с жезлом в руках перед Евангелием и Святыми дарами, и с криком поражающего теснящийся в чалмах народ». И тут же повествователь говорит о «необходимости иметь стражей, по буйству и взаимной вражде поклонников» [Там же, c. 164]. Сам повествователь в Лазареву субботу не смог слушать литургию на Элеоне, так как ему воспрепятствовал мятеж арабов. «По страху буйной черни» в Великий четверг обряд умовения ног был совершен наскоро и не на том месте, где омывал их Спаситель. Великая утреня была искажена «нестройными хорами и бесчувственностью толпы». В Великую субботу повествователь «не узнал собора! - он обратился в обширный базар. Арабы, их жены и дети сидели на мраморном помосте, корзины плодов и припасов лежали посреди толпы поклонников, разбитой по семьям; везде был говор и крик» [Там же, с. 220, 225].

Болью в сердце повествователя отзывается десакрализация крестного пути: «Ныне дикий араб быстро по нем несется на коне, клубами подымая за собой священный прах. Ныне презренный, порабощенный еврей малодушно идет

\footnotetext{
${ }^{6} \mathrm{Cp}$. описываемую Агасвером в разговоре с Наполеоном картину гибнущего Иерусалима, которая включает в себя такие знаковые детали, как разрушение главного храма города от рук внешних и внутренних грабителей, убийства первосвященников в храме, сопровождающиеся «бесстыдных оргий хохотом», «развратом песен». Кульминацией «ужасного боя» в Иерусалимском храме (в изложении Агасвера это было высшей степенью отхода от нормы) стало то, что храм запылал в тот самый миг, когда «под святотатной / Рукою скиния открылась» [Жуковский, 2009, с. 278]. В этих событиях герой впервые видит, как сбывается предсказанное Иисусом, и цитирует фрагмент Его пророчества.
} 
по сему поприщу, где его преступные предки призвали ему на главу ту священную кровь, которой некогда оно дымилось. <..> Но что всего больнее для сердца, ныне беспечный христианин равнодушно протекает вниз и вверх великую стезю сию, как будто не для него обагренную кровью, и чуждые, корыстные мысли развлекают его воображение, когда недостойная нога попирает след страданий Спасителя!» [Муравьев, 2006, с. 169]

«Пустыня Иорданская! - восклицает герой-повествователь, - все в твоем пространном объеме исполнено величия необычайного... И все ныне пусто и безмолвно.. < ..>. Земля оглохла, а небо закрыло уста свои над Иорданом» [Там же, c. 174].

Но более всего страдала душа русского поклонника в храме Гроба Господня, ключи от которого «к стыду христиан, находились в руках неверных. Несколько семейств искони откупили себе право владеть оными и получали по шести левов платы за каждое открытие Святых врат. <..> Угощаемые кофеем во время литургии, они сидели с трубками в преддверии» [Там же, с. 194]. Само здание храма описано обезображенным многочисленными пристройками, отражающими его многотрудную историю и историю христианства на Востоке.

Радость пребывания на Святой Земле постоянно омрачается проявлениями духовного и религиозного кризиса, переживаемого Палестиной. В их ряд встают и «странные и нелепые слухи» о том, что герой-повествователь - «начальник сильного отряда, посланного для завоевания Святого Града и что 10000 русских придут» вслед за ним из Эрзрума или пристанут на кораблях у Акры. Главным источником этих «толков» повествователь называет «искони распространенный на Востоке страх имени русского, умноженный теперь славой побед наших над Портой», «мнение, что мы завоюем некогда Иерусалим» [Там же, с. 161]. Эти слухи он рассеивает собственным поведением, демонстрируя своего рода модель русского присутствия в Палестине - доброжелательного, толерантного, гибкого, при сохранении внутренней цельности, которую сознательно выстраивает в себе на протяжении всего пути по Палестине. Герой-повествователь находится в постоянном диалоге с окружающим миром, преподнося окружающим уроки и получая уроки от них. Например, он вспоминает, как «кадий Иерусалимский... встревожился» его прибытием и просил его, «равно как и эмиры племени Магометова», показать им свой фирман. «Впоследствии они всегда приветствовали меня с величайшим уважением, предлагая розы или апельсины в знак приязни» [Муравьев, 2006, с. 161]. Показателен и диалог повествователя с архимандритом, целующим руку и полу одежды мусселима: упрекнув его за это, в ответ он получил извинения и объяснения такого поведения обычаем, «бременем ига», уважением в лице мусселима паши Дамасского, и наконец просьбу к России выступить гарантом правовых и религиозных отношений на Святой Земле: «...но придите оградить нас правами, - прибавил он, - и мы облобызаем милующую десницу вашу!» [Там же, с. 162]

Ярким примером русского присутствия в Палестине является поведение повествователя в храме Гроба Господня: «Мне открыли Храм Воскресения. Минуя все его святыни, я устремился прямо к Святому Гробу. <...> В невыразимом волнении духа простерся на ее мрамор. <..> Слезы умиления и благодарности полились из глаз моих. Но они обратились в горькие слезы, когда, опустясь мыслью к земному, я вспомнил позор Святого Града и всех великих его мест, позор самого Гроба, некогда искупленного кровью стольких тысяч, ныне одинокого, забытого в диких пустынях Палестины, посреди распрей христианских и гонения магометан» [Там же, с. 169]. Не менее показательны поступки повествователя во время службы в храме Гроба Господня в Великую субботу: оскорбленный поведением 
арабов, он усмиряет вспыхнувшее искушение ${ }^{7}$ силой прекратить бесчинства и обращается с твердой просьбой к мусселиму, не склоняя головы перед ним, «вывести гарем свой из галереи иконостаса; изумленный, он молчал; я ожидал ответа, и в сию минуту не решился он отказать. Тогда пошел я в патриархию. Многое сказал я архиереям в горести сердечной о попущении подобного бесчинства между христианами... Наместники извинялись игом турецким, заключением Храма, давним обычаем и, вероятно, приняли меня за безумного, видя, какое странное впечатление произвела на меня столь обыкновенная в том краю картина» [Муравьев, 2006, с. 227].

Здесь же обратим внимание на последовательное, хотя и неявное, сведенное в подтекст, сопоставление России и Святой Земли. Решительно, как и Жуковский, разрушая образ России-завоевательницы, Муравьев создает свой образ святой Руси, очень близкий к тому, что был создан первым поэтом-романтиком (см. об этом подробнее: [Айзикова, 2017]). Это - пространство, где сохраняются исконные основы веры, целостности и гармонии бытия, которые она дает, где хранятся и точно исполняются традиции Церкви и церковных служб и таинств, от поведения прихожан до звучания церковного хора и деталей одежды священников.

Особенно примечателен раздел в главе «Летопись храма» ${ }^{8}$, посвященный описанию «драгоценного слепка» Иерусалимского храма Воскресения Христова в Новом Иерусалиме. На фоне общего пафоса исторического повествования, который определяется идеей не прекращавшейся кровопролитной борьбы за храм, его разрушения, обезображивающих его видоизменений, Россия выступает хранительницей и созидательницей святыни: она «сохраняет в пределах своих драгоценный слепок сего Храма», очищая его от ненужных наслоений и даже подчеркивая, усиливая его объединяющую силу: «не должно искать совершенного сходства во всех частях между обоими зданиями, начиная с самой наружности, ибо зодчий не мог подражать нелепой массе строений, обезобразивших Храм Иерусалимский, и дал своему зданию величественный вид русских монастырей с многочисленными главами, не существующими в подлиннике. Внутреннее же расположение собора, часовни гроба, Голгофы и подземных церквей подобны образцу даже и самым размером... <...>. Сверх того все перегородки, которые разбивают на столько отдельных частей Храм Иерусалимский, уничтожены в Воскресенском и дают другой вид его внутренности» [Муравьев, 2006, c. 214].

Этим же настроением пронизано описание Нового Иерусалима, которым открывается «Путешествие по святым местам русским». Вся глава о Новом Иерусалиме, ставшем «особенно близким... сердцу с тех пор, как поклонился древнему образцу его» [Муравьев, 2014, с. 50], построена на сравнении архитектуры, богослужения 9 и, главное, чувств, пережитых героем-повествователем в Святой Земле и Иерусалиме и воскресших в русском Новом Иерусалиме. Приведем лишь один

\footnotetext{
${ }^{7} \mathrm{O}$ необычайной силе искушения на Святой Земле повествователь не раз слышал от иноков, знал из рассказов о жизни христианских святых. Этот же момент подчеркивается в «Странствующем жиде» Жуковского.

8 «Летопись храма» как слепок с летописи Иерусалима, получившая в дальнейшем более широкое описание в специальном труде Муравьева «История святого града Иерусалимского» (1844), очень близка иерусалимскому сюжету поэмы Жуковского «Странствующий жид»: выделяются те же исторические периоды, называются те же имена, передается тот же авторский пафос.

${ }^{9}$ Особенно подробно это освещено в «Письмах с Востока», гл. «Подробности о Иерусалиме». С горечью Муравьев пишет о скорости разрушения храма: «Многое изменилось даже со времени моего первого путешествия. $<\ldots>$ Грустно, что ни мы, ни франки не успели выпросить себе оставленного тогда храма» [Муравьев, 1851, с. 177].
} 
пример: описывая Воскресенский собор, повествователь отмечает, что его вид «совершенно отличен от образца своего. Правда, и там (в Иерусалимском храме Гроба Господня. - И. А.) есть два купола над собором и полукупол над алтарем... но все без крестов и все кругом застроены террасами и плоскими крышами соседних монастырей Авраама и абиссинцев и древнею Патриархией... все же здание является в виде огромной полуразрушенной твердыни... А здесь напротив, все еще ново и свежо: четыре малые часовни... окружают большой купол... две легкие главы, по обеим сторонам соборного алтаря... довершают стройную красоту здания. <..> Забывшись, можно подумать, что таким был некогда и священный его подлинник» [Муравьев, 2014, с. 51-52]. Лейтмотивом всех описаний становятся слова повествователя: «Я в Палестине». Кроме того, важно отметить последовательное подчеркивание повествователем ведущей роли русских царей в истории Нового Иерусалима.

Возвращаясь к характеру описания Святых мест в «Путешествии...» Муравьева, обратимся к одному важному мотиву, появившемуся еще в его ранней трагедии о Тивериаде и наиболее очевидно перекликающемуся с позицией Жуковского - предопределенности Божьей волей земной трагедии Палестины и ее центра Иерусалима, предназначенной для того, чтобы снять завесу с будущего человечества и открыть ему Новый Иерусалим и нового человека, готового жить по заветам Христа. Прощаясь в Вифании со Святой Землей, повествователь восклицает: «Все ветхое миновалось. Мгла неизвестности над Иерусалимом. <..> Иерусалим избран поприщем для поединка» [Муравьев, 2006, с. 270].

В этих контекстах и звучит в «Путешествии...» Муравьева предложение о спасении Гроба Господня и о высокой миссии России в этом деле: «Кто был и молился над Гробом Спасителя посреди позора и бесчестия, которому он предан, кто вместе с слезами покаяния оросил его слезами тщетной горести, тот не может постигнуть равнодушия Европы к сему основному камню ее спасения. Не о крестовых битвах речь, не о новом движении Запада на Восток; дни крови миновались, настало время договоров, и западные державы отступились от Иерусалима, когда Россия, избранная Провидением... так грозно выступила на свое высокое поприще. Она одна только может облегчить участь Святого Града». И ниже: «...сильно и жалостно, в рубище и язвах, вопиет о помощи единоверная церковь иерусалимская к православному отечеству, которого мощная десница одна только в силах охранить единственное в мире сокровище для христиан - Гроб Искупителя!» [Там же, 230, 264] ${ }^{10}$

Мысли Муравьева почти буквально совпадают с предложением Жуковского, высказанным в конце 1840-х гг. в письмах к великому князю Константину Николаевичу: «...место, где совершилось спасение человечества, место, освященное земною жизнию и искупительною смертию Спасителя, не должно оставаться во власти врагов его. Если мы христиане в настоящем значении этого слова, то для нас гроб Спасителя не есть один исторический памятник: это высочайшая человеческая святыня, это видимый пункт на земле, где наша жизнь соединяется, посреди временного, с небесным и вечным. <..> Как же изъяснить то равнодушие, с каким Европа, вся христианская и столь могущественная своим общественным развитием, смотрит на осрамление ее святейшего сокровища? <..> $\mathrm{O}$ ! по всем сердцам ударит молния вдохновения и восторга, когда наш великий царь... скажет в совете царей: “отдадим Богу Божие; святой гроб Спасителя и святой град, его в себе заключающий, должны принадлежать не России, не Англии, не Франции и пр. с одной стороны, и не туркам с другой - они должны

\footnotetext{
${ }^{10}$ Муравьев предлагает, наряду с договорами, даже выкуп храма Гроба Господня: «Мне кажется еще возможно силой денег и договоров исторгнуть сие святилище из рук неверных» [Муравьев, 2006, с. 236].
} 
принадлежать Богу Спасителю”. <..> А какие последствия могли бы быть для христианства, для соединения всех церквей... когда бы около гроба Спасителя, около одного общего средоточия, все исповедания соединилися на свободе с чувством одной, всех сближающей, все миротворящей веры» [Жуковский, 1878, c. 378-379].

Совпадает и сформулированное обоими писателями условие успеха освобождения Гроба Господня - его мирная реализация: ср. у Жуковского: «Это не будет вызов на неправедное завоевание, на насильственное отнятие собственности, утвержденной давностью владения». И ниже: «я не крестовую войну проповедую. Пролитие крови за Христа или в честь Христа есть святотатство» [Там же, c. 378$]$.

Особой заботой Жуковского и Муравьева было и то, чтобы «и при самом освобождении Храма Гроб Господний» оставался «общею святынею для избежания распрей между различными исповеданиями» [Муравьев, 2006, с. 264]. И здесь, как видим, прямые совпадения в позициях Жуковского и Муравьева, размышляющих о формах русского присутствия в Палестине. Повествующий герой «Путешествия...» придает чрезвычайно большое значение проявлению на Святой Земле толерантности и, в первую очередь, установлению личных связей и контактов между христианами: православными, католиками, представителями Армянской апостолькой церкви, Грузинской православной церкви. Особой территорией их сближения является Палестина и общее дело - поддержка христианства на Востоке, забота о Гробе Господнем и других Святых местах, которые незримо ориентируют и гармонизируют жизнь христиан всего мира, определяя их религиозное, историческое и культурное сознание.

В этом плане особенно важна в «Путешествии...» Муравьева глава «Вероисповедания», открывающаяся программным заявлением повествователя: «Пять различных вероисповеданий... теснятся ныне вокруг общей им святыни Гроба... Но между ними и неправославные заставляют забыть свои заблуждения верностью великой могиле... В душе рождается не враждебное к ним чувство, когда в один торжественный час разноглагольное пение подымается во мраке святилища и облака многоплеменного фимиама из всех частей храма стекаются к часовне Святого Гроба». Рассуждая далее о разногласиях халдеев и коптов, герой-повествователь утверждает: «Не разность в вере их разделяет, но разность племени, языка и нескольких обрядов, вкравшихся в их церкви от долговременного разрыва» [Там же, с. 216, 218].

Глава заканчивается обобщением этой мысли: «Все... обременены тяжким игом магометан, исказивших нравственное их достоинство и потворствующих раздорам. Что же чудного в их взаимной ненависти? <..> Не в оправдание сих горестных христианству распрей говорю я, но только для должного к ним снисхождения» [Там же, с. 219].

Покидая Иерусалим, повествователь испытывает сложнейшее чувство, в котором слилось ощущение «невозвратной потери», устремленность к другой цели отчизне, спокойствие и благодать, проливаемые в душу последней молитвой перед Гробом Господним. В путь повествователя провожают благословения священников Иерусалимского храма Воскресения Христова, слезы и «целования» с остающимися в Палестине русскими поклонниками, с греческими монахами, «молебные пения» арабских священников Иерусалима. И наконец «торжественная тишина... была последним впечатлением Сиона» на сердце повествующего героя: «Одинокий, низко поклонился я Святому Граду, и быстро умчал меня конь из его очарований!» [Там же, с. 272] Ср. с описанием прощания с Иерусалимом в «Письмах с Востока»: «Я еще отслушаю сегодня одну торжественную вечерню, в храме Воскресения, а завтра литургию на Голгофе, и потом пойду в дальний 
путь мой; но, лучше ли я теперь, чем пришел сюда? Вот тяжкий для меня вопрос, который разрешат только время и вечность» [Муравьев, 1851, с. 294].

Таким образом, мы видим, что подход к пониманию темы Иерусалима (и Палестины в целом) был весьма близким у Жуковского и Муравьева. Так же близки они были, в силу объединяющего их исторического периода, в стремлении к интенсивному взаимопроникновению художественного и религиозного начал в «палестинском нарративе», опираясь на их общие конститутивные особенности: категорию личности и категорию слова. Однако в духовной прозе Муравьева очевидно облачение религиозного высказывания в художественный текст, что ставит его на грань между литературой и теологий. Важнейшую черту его сочинений о Палестине и Иерусалиме можно определить, используя слова М. М. Бахтина, как «причастную вненаходимость» Бога, выступающего в качестве субъекта, объекта и адресата высказывания, художественно оформленного. Это - духовная практика глубоко верующего человека, в которой религиозное начало является органической частью эстетического целого. У Жуковского воплощение палестинской темы связано с воображаемым субъектом и миром и эстетически творящим автором. Религиозное начало в сочинениях Жуковского о Святой Земле растворено в художественном, оно отсылает к его ценностным установкам, существуя в них как пратекст. За этими различиями, подчеркнем, опознаются общие интенции: художественные задачи и духовно-религиозные цели писателей сближаются, определяя их онтологическую близость. Тема Палестины, с ее выходами в историю и антропологию, явилась плодородным полем для соединения художественного и религиозного.

Иерусалимские проекты Жуковского и Муравьева подтверждают данный вывод. Если Жуковский воспринимал свой Иерусалимский проект как «поэтическое» событие, «сияющее» перед его воображением, долженствующее, наконец, объединить идеал и действительность, чего не удалось добиться ни ему, с помощью перевода гомеровской поэмы, ни проведенными наследником престола блестящими военными операциями, то за размышлениями Муравьева в «Путешествии...» последовали вполне конкретные события и действия, направленные на укрепление личной веры, утверждение русского присутствия в Палестине и весьма примечательная карьера писателя. Так, на пути в Иерусалим, Муравьев впервые в жизни соблюдал Великий пост, по возвращении впервые провел в говении летний Успенский пост, почувствовал необходимость изучать церковную историю. А. Каплин в «Предисловии» к переизданию «Путешествия по святым местам русским» справедливо указывает, что «Иерусалиму он был обязан первыми своими сведениями об истории Вселенской Церкви и учении святых отцов, и это был первый его самостоятельный шаг на духовном поприще» [Муравьев, 2014 , с. 15]. По возвращении из Святой Земли Муравьев знакомится со многими духовными лицами России (архимандритами Фотием и Палладием, митрополитами Серафимом и Филаретом и др.), продолжает начавшиеся в Палестине и завязывает новые отношения с церковными деятелями, состоит с ними в многолетней переписке «по догматическим, церковно-политическим, должностным вопросам» [Там же, с. 37], отправляется в путешествие по святым местам русским. Посещая Палестину в 1829 г. уже будучи определенным в Коллегию иностранных дел, позднее он был назначен столоначальником турецкого стола в Азиатском департаменте МИДа, потом становится обер-секретарем в Святейшем Синоде. Более 20 лет Муравьев считался эпитропом Иерусалимского патриаршего престола. Жизнь его была посвящена духовной прозе ${ }^{11}$, синодальной деятельности ${ }^{12}$ и на-

${ }^{11}$ А. Н. Муравьева, оставившего целую библиотеку духовной прозы, называют родоначальником новой разновидности духовной и церковной литературы. По характеристике А. С. Стурдзы, призвание Муравьева заключалось в том, «чтобы сблизить и сроднить 
родной дипломатии. Его труд на этом поприще не только способствовал диалогу культур России и Палестины, но и, по справедливому утверждению исследователей, формировал в русском обществе «живое заинтересованное отношение к судьбам Святой Земли» ${ }^{13}$, в целом влиял на религиозно-историческое и культурное общественное сознание России.

\section{Список литературы}

Айзикова И. А. Жанрово-стилевая система прозы В. А. Жуковского. Томск, 2004. $403 \mathrm{c}$.

Айзикова И. А. Образ Палестины в творчестве В. А. Жуковского. Статья первая // Вестн. Том. гос. ун-та. Филология. 2015. № 5. С. 124-144.

Айзикова И. А. Образ Палестины в творчестве В. А. Жуковского. Статья вторая // Вестн. Том. гос. ун-та. Филология. 2016. № 2. С. 94-108.

Айзикова И. А. К проблеме контекста Иерусалимского проекта В. А. Жуковского (по материалам политической публицистики и религиозно-философской прозы 1840-х гг.) // Вестн. Том. гос. ун-та. Филология. 2017. № 46. С. 95-112.

Айзикова И. А. Тема Палестины в творческом диалоге В. А. Жуковского и А. Н. Муравьева. Статья первая // Сибирский филологический журнал. 2018. № 2. C. 67-78.

Гоголь Н. В. Полное собрание сочинений и писем: В 17 т. Т. 15. Москва, Киев, 2009. $816 \mathrm{c}$.

Гуминский В. М. Путешествие Гоголя по Святой Земле в контексте развития паломнической литературы // Новая книга России. 2011. № 11-12. URL: http:// www.voskres.ru/literature/critics/guminskiy1.htm (дата обращения 24.12.2017).

Жуковский В. А. Сочинения: В 6 т. 7-е изд. СПб., 1878. Т. 6.

Жуковский В. А. Полное собрание сочинений и писем: В 20 т. Т. 4. М., 2009. $636 \mathrm{c}$. $30 \mathrm{c}$.

Казанский П. С. Воспоминание об Андрее Николаевиче Муравьеве. М., 1877.

Муравьев А. Н. Письма с Востока в 1849-1850 годах. Ч. 2. СПб., 1851. 437 с.

на Руси изящную словесность с духовною» [Стурдза, 1994, с. 58]. Профессор Московской духовной академии П. С. Казанский писал, что главное достоинство и заслуга Муравьева «как духовного писателя заключается не столько в достоинстве самих сочинений, сколько в том влиянии, какое имели эти сочинения на русское общество. $<\ldots .>$ Он заставил высшее общество читать книги духовного содержания, писанные по-русски. Он познакомил это общество с учением Православной Церкви, объяснил дух ее богослужения» [Казанский, 1877 , с. 8]. Современный исследователь В. Гуминский также считает, что «в истории русской литературы изменение отношения к паломническому жанру... связывают в первую очередь с именем А. Н. Муравьева» [Гуминский, 2011]. Сам Муравьев писал в конце жизни: «Я, можно сказать, создал церковную литературу нашу, потому что первый облек в доступные для светских людей формы все самые щекотливые предметы богословские и полемические...» («Мои воспоминания» А. Н. Муравьева (неопубликованная часть) цит. по: [Хохлова, 2001, с. 188]). В 1837 г. А. Н. Муравьев за заслуги в области российской словесности был избран Почетным членом Российской Академии, а позднее - Императорской Санкт-Петербургской Академии наук по Отделению русского языка и словесности (с 21 ноября 1841 г.). В 1871 г. Муравьев был избран членом Московской и Киевской Духовных Академий.

12 А. Н. Муравьев, как известно, причастен к возникновению Русской духовной миссии в Иерусалиме.

13 Лисовой Н. Н. Русское духовное присутствие в Святой Земле в XIX - начале XX в. Исторический очерк о Русской Духовной миссии в Палестине. URL: http://www.ippo.ru/ historyippo/article/russkoeduhovnoe-prisutstvie-v-svyatoy-zemle-v-xix-200501 (дата обращения 24.12.2017) 
Муравьев А. Н. Путешествие ко Святым местам в 1830 году. М.: Индрик, 2006. $344 \mathrm{c}$.

Муравьев А. Н. Путешествие по Святым местам русским / Сост., предисл., примеч. А. Д. Каплина. М.: Ин-т русской цивилизации, 2014. 768 с.

Пушкин А. С. Полное собрание сочинений: В 10 т. Т. 7. М., 1964.765 с.

Стурдза A. С. Беседа любителей русского слова и Арзамас в царствование Александра I и мои воспоминания // Арзамас: Сб. в 2 кн. Кн. 1. М., 1994. С. 42-59. Хохлова Н. А. Андрей Николаевич Муравьев - литератор. СПб., 2001. 244 с.

\author{
I. A. Ayzikova \\ Tomsk State University \\ Tomsk, Russian Federation, wand2004@mail.ru
}

\title{
The theme of Palestine in the creative dialogue of V. A. Zhukovsky and A. N. Muravyov The second article
}

The paper considers the ideas of A. N. Muravyov in his "Puteshestvie po Svyatym mestam russkim" [Journey to the Holy places of Russia]. In the 1840s, this work attracted the attention of V. A. Zhukovsky and the ideas found their reflection in his religious-philosophical, journalistic prose, letters and the poem "The Wandering Jew." The most significant of them are related to the interpretation of Jerusalem shrines as a metaphysical phenomenon that could answer to all vexed questions of the history and modern times, associated with striving to liberate the Tomb of Jesus from the Turkish Sultan. Special attention is paid to Russia and the image of the Russian Tsar capable of performing a God-directed mission. The analysis of the materials mentioned above has shown that Muraviev's and Zhukovsky's approaches to understanding the Jerusalem theme (and Palestine in general) were very similar. The resemblance is due to their spiritual quests and ideological affinity being similar, largely dictated by time. However, in Muraviev's spiritual prose, the religious statements are obviously integrated into the literary text, putting it on the edge between literature and theology. Zhukovsky's ideas on the Palestine theme are connected with an imaginary hero, world, and creating author. Zhukovsky's works on the Holy Land transform the religious aspect into the literary one, referring to his system of values presenting a paratext in both of them. It is should be emphasized that similar intentions are identified through these differences: the writers' artistic tasks and spiritual-religious goals come together, defining the synthesis of artistic and religious ideas, proving their ontological similarity.

Keywords: V. A. Zhukovsky, A. N. Muravyov, the theme of Palestine, creative dialogue.

DOI $10.17223 / 18137083 / 66 / 5$

\section{References}

Ayzikova I. A. K probleme konteksta Ierusalimskogo proekta V. A. Zhukovskogo (po materialam politicheskoy publitsistiki i religiozno-filosofskoy prozy $1840-\mathrm{kh}$ gg.) [To the context problem of the Jerusalem project of V. A. Zhukovsky (political essays and religious and philosophical prose of the 1840s)]. Tomsk State University Journal of Philology. Tomsk, 2017, no. 46, pp. 95-112.

Ayzikova I. A. Obraz Palestiny v tvorchestve V. A. Zhukovskogo. Stat'ya pervaya [The image of Palestine in the work of V. A. Zhukovsky. Article 1]. Tomsk State University Journal of Philology. Tomsk, 2015, no. 5, pp. 124-144.

Ayzikova I. A. Obraz Palestiny v tvorchestve V. A. Zhukovskogo. Stat'ya vtoraya [The image of Palestine in the work of V. A. Zhukovsky. Article 2]. Tomsk State University Journal of Philology. Tomsk, 2016, no. 2, pp. 94-108.

Ayzikova I. A. Tema Palestiny v tvorcheskom dialoge V. A. Zhukovskogo i A. N. Murav'yeva. Stat'ya pervaya [Palestine in the creative dialogue of V. A. Zhukovsky and A. N. Muravyov. Article 1]. Siberian Journal of Philology. 2018, no. 2, pp. 67-78. 
Ayzikova I. A. Zhanrovo-stilevaya sistema prozy V. A. Zhukovskogo [The genre and stylistic system of V. A. Zhukovsky's prose]. Tomsk, 2004, 403 p.

Gogol' N. V. Polnoe sobranie sochineniy i pisem: V 17 t. T. 15 [Complete works and letters: in 17 vols. Vol. 15]. Moscow, Kiev, 2009, 816 p.

Guminskiy V. M. Puteshestvie Gogolya po Svyatoy Zemle v kontekste razvitiya palomnicheskoy literatury [Gogol's journey to the Holy Land in the context of the pilgrimage literature development]. Novaya kniga Rossii. 2011, no. 11-12. URL: http://www.voskres.ru/literature/ critics/guminskiy1.htm (accessed 24.12.2017).

Kazanskiy P. S. Vospominanie ob Andree Nikolaeviche Murav'eve [Memoirs on Andrei Nikolaevich Muravyov]. Moscow, 1877, 30 p.

Khokhlova N. A. Andrey Nikolaevich Murav'ev - literator [Andrey Muravyov - a writer]. St. Petersburg, 2001, 244 p.

Murav'ev A. N. Pis'ma s Vostoka v 1849-1850 godakh. Ch. 2 [Letters from the East 18491850]. St. Petersburg, 1851, 437 p.

Murav'ev A. N. Puteshestvie ko Svyatym mestam v 1830 godu [Journey to the Holy places in 1830]. Moscow, Indrik, 2006, 344 p.

Murav'ev A. N. Puteshestvie po Svyatym mestam russkim [Journey through the Holy places of the Russian]. A. D. Kaplin (Comp.). Moscow, 2014, 768 p.

Pushkin A. S. Polnoye sobraniye sochineniy: V 10 t. T. 7 [Complete works: in 10 vols. Vol. 7]. Moscow, 1964, $765 \mathrm{p}$.

Sturdza A. S. Beseda lyubiteley russkogo slova i Arzamas v tsarstvovanie Aleksandra I i moi vospominaniya [Conversation of the lovers of the Russian word and Arzamas in the reign of Alexander I and my memories]. In: Arzamas: Sb. v 2 kn. Kn. 1 [Arsamas: Coll. in 2 bks. Bk 1]. Moscow, 1994, 42-59.

Zhukovskiy V. A. Sochineniya: V 6 t. 7-e izd. T. 6 [Works: in 6 vols. The 7th ed. Vol. 6]. St. Petersburg, 1878.

Zhukovskiy V. A. Polnoe sobranie sochineniy i pisem: V 20 t. T. 4 [Complete works and letters: in 20 vols. Vol. 4]. Moscow, 2009, 636 p. 